\title{
Drug protocols for patients with special needs: a review of the literature
}

\author{
Protocolos farmacológicos em pacientes portadores de necessidades especiais: uma revisão de literatura \\ Lucas Lacerda de Souza' \\ (i) ORCID iD 0000-0002-9481-7796 \\ Márcia Andréa Macedo do Nascimento \\ (iD) ORCID iD 0000-0003-1270-5844 \\ Ronan Lira de Lima' \\ (i) ORCID iD 0000-0003-3700-9466 \\ Letticia Nakano Rangel de Oliveira ${ }^{1}$ \\ (iD) ORCID iD 0000-0003-3597-0755 \\ Anderson Luan dos Santos Ramos ${ }^{1}$ \\ (i) ORCID iD 0000-0001-8222-5155 \\ Grace Bruna Ferreira Marques' \\ (D) ORCID iD 0000-0001-8500-944X \\ Aline Costa Flexa Ribeiro Proença ${ }^{1}$ \\ (D) ORCID iD 0000-0001-5236-0006 \\ Erick Nelo Pedreira' \\ (D) ORCID iD 0000-0001-5771-2293
}

\section{ABSTRACT}

There is a great need for dental surgeons to be trained to proceed with patients needing some kind of special care. This study aimed to perform a review of the literature on drug protocols concerning how to treat patients with special needs, within the different areas in which dentists may be engaged. The methodology employed was to review articles dealing with the subjects of diabetes mellitus, chronic renal failure, hemophilia, cardiac patients, which were focused on areas of dentistry. A total of 33 articles were selected. Several specific protocols were found on how to act during a consultation of several systemic diseases or in special cases, in order to achieve success during treatment, to avoid drug interactions or to create emergency situations. It was possible, in some cases, to find a consensus between the sequences or the drug of first choice for patients. Serious errors can occur if a dentist is not capable in serious cases. The creation of a protocol for these patients in the different dental specialties would reduce the number of failed treatments, thus increasing the safety and effectiveness of the treatments.

Indexing terms: Dentistry. Pharmacology; Protocols. Disabled persons.

\section{RESUMO}

Há uma grande necessidade dos cirurgiões-dentistas estarem capacitados para proceder diante de pacientes com algum tipo de cuidado especial. Esse trabalho teve como objetivo realizar uma revisão de literatura sobre protocolos farmacológicos de como tratar pacientes portadores de necessidades especiais, dentro das diversas áreas que os cirurgiões-dentistas podem atuar. Métodos: Foi adotada como metodologia a revisão de artigos nos temas de Diabetes Mellitus, insuficiência renal crônica, hemofilia, pacientes cardiopatas, no período de 1980 a 2017 todos voltados para áreas da odontologia. Resultados: Foram selecionados 33 artigos da temática. Foram encontrados vários protocolos específicos para agir durante uma consulta de diversas doenças sistêmicas ou em casos especiais, afim de conseguir o sucesso durante o tratamento, evitar interações medicamentosas ou criar situações de emergências. Foi possível verificar, em alguns casos, um consenso entre as sequências ou o medicamento de primeira escolha para os pacientes portadores de necessidades especiais. Podem acontecer erros graves caso algum cirurgião-dentista não esteja capacitado para realizar a consulta nesses casos graves. A criação de um protocolo para esses pacientes nas diversas especialidades odontológicas diminuiria a quantidade de tratamentos com insucesso, assim aumentando a segurança e a eficácia dos tratamentos.

Termos de indexação: Odontologia. Farmacologia. Protocolos. Pessoa com deficiência.

\section{INTRODUCTION}

According to the Federal Dental Council, Patients with Special Needs (PSNs) are those who need special care as a result of some deviation from the norm, whether or not they have been specifically identified as such ${ }^{1}$. It is necessary to conceptualize special needs patients taking into account the clarification of the didactics of clinical exercise so that specialized and channelized treatment can be provided ${ }^{2}$.

The prospects of success in any dental treatment depends on the dental surgeon's understanding of the patient, planning which is achieved via a thorough anamnesis ${ }^{3}$.

\footnotetext{
${ }^{1}$ Universidade Federal do Pará, Instituto de Ciência da Saúde, Faculdade de Odontologia. Rua Augusto Corrêa, 1, Guamá, 66075-110, Belém, PA, Brasil. Correspondência para / Correspondence to: LL SOUZA. E-mail: <lucaslac@hotmail.com>.

$\boldsymbol{\nabla} \mathbf{v} \boldsymbol{\nabla}$

Como citar este artigo / How to cite this article

Souza LL, Nascimento MAM, Lima RL, Oliveira LNR, Ramos ALS, Marques GBF, et al. Drug protocols for patients with special needs: a review of the literature. RGO, Rev Gaúch Odontol. 2018;66(1):77-81. http://dx.doi.org/10.1590/1981-863720180001000093348
} 
PSNs have already been defined as special patients. The concepts and clarifications have changed over time as a result of the wider scope of the innumerable alterations in these individuals' physical, mental or social characteristics ${ }^{2}$. Theoretically, they are people who present with a condition emanating from a biological, physical, social or mental change, necessitating a multi-professional approach $^{1-2}$.

The American Academy of Pediatric Dentistry reports that PSNs present with changes that create limitations on patients' daily routines. As a result, a monitoring by specialized services is needed as well as permanent care, with the aim of providing social inclusion for this class ${ }^{4}$.

Coming from a biopsychosocial perspective, the World Health Organization created the International Classification of Functioning, Disability and Health (ICF), with the aim of creating a database that, over time, supplies information about these patients between countries and specific regions ${ }^{5}$.

The classification, according to the International Dental Association for Patients with Special Needs (IADH - International Association for Disabilities and Oral Health) divides these patients into 10 classifications that facilitate an understanding of the specific care protocols, which include: 1. Learning difficulties; 2. Physical defects; 3. Congenital defects; 4. Behavioral deviations; 5. Psychic deviations; 6. Sensory and audio-communication deficiencies; 7. Chronic systemic diseases; 8. Endocrine metabolic diseases; 9. Social deviations; 10. Special physiological conditions 6 .

Given this view, the treatment of special needs patients begins with a detailed anamnesis and physical examination. The dental surgeon, in his/her role as health professional, needs to possess not only an understanding related to the diagnosis of the various disorders, but also a knowledge of previous treatments undergone by the patients ${ }^{7}$. Faced with systemic changes, peculiarities should be identified so the treatment can focus on the needs of these individuals ${ }^{8}$.

The aim of this study was to perform a review of the literature in respect of the drug protocols in dentistry used with special needs patients, with the aim of establishing the influence of these drugs and their application in patients with diabetes mellitus, chronic renal insufficiency, hemophilia, cardiomyopathies, anemia or pregnancy.

\section{Diabetes Mellitus}

Diabetes mellitus (DM) is characterized by the group of metabolic disorders that correspond to a presentation of hyperglycemia, generated by abnormalities in the action of insulin ${ }^{9-10}$. Etiologically, this disturbance involves three subtypes: Type 1, type 2 and gestational $\mathrm{DM}^{11}$.

Diabetic patients present with physiological changes that affect immunological capacity and inflammatory response, increasing the risk of infection ${ }^{12}$.

In patients who have DM, symptoms occur such as polydipsia, polyuria, polyphagia and weight loss. Hyperglycemia generates microcirculatory abnormalities, retinopathy, nephropathy (kidney disease) and peripheral neuropathies. Moreover, they produce disorders in the healing process and a greater tendency to produce cerebrovascular, cardiovascular and lymphatic vessel atherosclerosis ${ }^{13}$.

As far as the oral region is concerned, DM principally triggers periodontal disease and may be considered as the primary vascular complication of diabetes. Clinical trials have shown that individuals with type 2 DM tend to develop a greater prevalence of periodontal abscesses when compared to non-diabetics ${ }^{14}$. In addition to periodontal disease, other oral complications arising from DM include xerostomia, hyposalivation, oral candidiasis, taste disorders, caries and enamel hypoplasia ${ }^{15}$.

Drug prescriptions written by dentists have to be very cautious. Non-steroidal anti-inflammatory drugs (NSAIDs) and cephalexin (a beta-lactam antibiotic) can boost the effects of oral anti-diabetic medication, increasing the risk of hypoglycemia, while steroidal anti-inflammatory drugs (corticoids) can aggravate hyperglycemia. The prescription of these drugs must be scrupulous, it being necessary to contact the team physician in order to establish dosage16. Prolonged use of topical steroids (for a continuous period in excess of two weeks) may result in atrophy of the oral mucosa and secondary candidiasis ${ }^{17}$. The presence of uncontrolled DM is an absolute contraindication to the use of adrenergic vasoconstrictors combined with local anesthetic. In the event of a formal contraindication to the use of adrenergic vasoconstrictors, felypressin is an option ${ }^{18}$.

\section{Hemophilia}

Hemophilia is a genetic disturbance marked by prolonged bleeding caused by a reduction or absence of one of the coagulation factors needed to form a blood clot. The disease, caused by the deficiency of the gene 
that modifies the organism's ability to produce sufficient factors that produce clotting, affects approximately one in every eight thousand people ${ }^{19}$. The two most common forms are hemophilia A, characterized by the quantitative deficiency of factor VIII, also known as classic hemophilia, and hemophilia B, also known as Christmas disease, characterized by a quantitative deficiency of factor IX ${ }^{20}$.

Controlling dental pain in patients with coagulopathies should be done with paracetamol derivatives or dipyrone. Aspirin and its derivatives are contraindicated as a result of its activity that inhibits platelet aggregation. The use of anti-inflammatory drugs in these patients should be restricted because of their antiaggregation effects. The hematologist must be consulted before these are prescribed ${ }^{21}$.

For periodontal treatment, gauze compresses soaked in antifibrinolytics, balls of cotton wool soaked in 10\% trichloroacetic acid (TCA), surgical cement and, if necessary, the administration of oral antifibrinolytics, may be used where there is potential bleeding caused by scraping, which can be controlled locally ${ }^{21}$.

In cases of oral surgery, due diligence is required to avoid bigger problems. Correct antihemorrhagic treatment applied at the right moment is sufficient to produce the clot in the tooth extraction wound ${ }^{22}$. The anesthetic injection should be applied slowly, it being necessary to apply coagulation factor in cases of a blockage of the inferior alveolar and lingual nerve, and whenever possible, avoid trunk and block anesthesia, as these may produce hematomas ${ }^{23}$.

\section{Cardiopathies}

The term cardiopathy relates to all diseases that affect the heart. These comprise a lack of flow and/or oxygen in the blood that circulates through the heart muscle, causing a blockage in the coronary arterial structure, as a result of atheromas ${ }^{24-25}$. The pathologies that present the greatest risk of impairment are angina pectoris, myocardial infarction, congestive cardiac insufficiency, arrhythmias and bacterial endocarditis ${ }^{26}$.

Cardiopathic patients must receive a more cautious dental treatment. The professional must pay attention to two special care situations: the first is the risk of developing infectious endocarditis, since this requires specific prophylactic measures oriented by the norms for the prevention of infectious endocarditis published by the American Heart Association (AHA $)^{24}$.

It is important to bear in mind the risk of drug interactions, to consider cardiac disease and its seriousness. In dentistry, lidocaine is regarded as the safest, intermediate duration anesthetic and is therefore considered the reference drug with properties of antiarrythmic, anticonvulsive, anti-inflammatory and antimicrobial therapeutic value. Bupivacaine is recommended for longer procedures, however, it is cardiotoxic as it has an attraction for cardiac fibers, being contraindicated for cardiopathic patients. Prilocaine is the reference drug for use in dentistry as it possesses felypressin as a vasoconstrictor that does not induce blood pressure variations. However, it is rapidly degraded by hepatic amidases ${ }^{25-26}$

Endocarditis is an infection of the myocardium by bacteria, such as those present in the saliva. The prophylactic regimen of endocarditis, patient risk classification and the procedures requiring antibiotic prophylaxis have been established by the American Heart Association 21. Amoxicillin is the drug of choice as it has few side effects and is very effective against microorganisms that cause endocarditis, the recommendation being a single preoperative dose of $2 \mathrm{~g}$ by oral administration, 1 hour before the procedure. For those patients who are allergic to penicillin, erythromycin is no longer indicated due to its gastrointestinal side effects. Instead, $600 \mathrm{mg}$ of clindamycin or alternatively other options such as azithromycin, clarithromycin or cephalosporin may be used. For children, the recommended dose is $50 \mathrm{mg} / \mathrm{Kg}$ of body weight via oral administration, one hour prior to the procedure $26-27$

\section{Chronic renal insufficiency}

This is a progressive disease defined as occurring when the kidneys are unable to perform their normal excretory functions. The byproducts of protein metabolism, such as urea, accumulate in the blood, producing changes in the body's various systems and in the kidneys. The deficiencies end up being life-threatening ${ }^{28}$.

Patients with chronic renal disease have systemic and oral conditions that require special precautions during dental treatment. The medication must be administered with caution and patients subjected to dialysis must receive special attention. Before beginning any dental treatment, the dental surgeon must consult the patient's physician with regard to the specific pecautions ${ }^{28-29}$.

Patients subjected to dialysis are more susceptible to developing infectious processes due to their overall condition, with a probable reduction in the efficiency of the immune system and masking of the signs and 
symptoms of infection by the drugs employed. These infections are the causes of morbidity and mortality in patients with uremic syndrome and, therefore, antibiotic therapy/prophylaxis should always be prescribed ${ }^{28-30}$.

As far as antibiotic prophylaxis in patients with chronic renal insufficiency is concerned, vancomycin is an option for patients not undergoing hemodialysis. The only restriction with this drug is the need to be hospitalized, which is generally recommended for individuals suffering from this abnormality ${ }^{31}$.

Classes of drugs exist that produce gingival hyperplasia, such as nifedipine and cyclosporine, it being necessary to control this via instruction on oral hygiene by means of techniques developed by the dental surgeon, in order to avoid the buildup of bacterial plaque ${ }^{31-32}$.

In addition, it is necessary to take into account the level of nephrotoxicity of drugs such as tetracycline, aspirin, non-steroidal anti-inflammatory drugs such as ibuprofen and naproxen ${ }^{11,31-32}$. Drugs like ampicillin, cephalexin, amoxicillin and acyclovir require a reduced dose in order to avoid side effects ${ }^{33}$.

\section{CONCLUSION}

In the field of dentistry, drug protocols must be performed taking into account the peculiarities of each patient. These characteristics are evidenced by means of a rigorous anamnesis and physical examinations of the patient in the dental surgery itself. It is the dental surgeon's responsibility to understand the various classes of drugs and their functionality and side effects in individuals with special needs.

\section{REFERENCES}

1. Santos MTBR, Haddad AS. Quem são os pacientes com necessidades especiais? In: Cardoso RJA, Machado MEL. Odontologia Arte e Conhecimento. São Paulo: Artes Médicas; 2003. p.263-8.

2. Dualibi SE, Dualibi MT. Uma nova visão sobre conceito e classificação em pacientes especiais. Rev Paul Odontol. 1998;(2):28-33.

3. Varellis MLZ. Conceituando o paciente com necessidades especiais. In: Varellis MLZ. O paciente com necessidades especiais na odontologia: manual prático. São Paulo: Santos; 2005. p. 3-12.

4. American Academy of Pediatric Dentistry. Definition of persons with special health care needs [cited 2017 Apr 2]. Available from: < http://www.aapd.org/media/Policies_Guidelines/D_

\section{Collaborators}

LL SOUZA, conception and design, acquisition of data, statistical analysis, drafting the article, revising the article critically for important intellectual content, final approval of the version to be published. MAM NASCIMENTO, conception and design, acquisition of data, statistical analysis, drafting the article, revising the article critically for important intellectual content, final approval of the version to be published. RL LIMA, conception and design, acquisition of data, statistical analysis, drafting the article, revising the article critically for important intellectual content, final approval of the version to be published. LNR OLIVEIRA, conception and design, acquisition of data, statistical analysis, drafting the article, revising the article critically for important intellectual content, final approval of the version to be published. ALS RAMOS, conception and design, acquisition of data, statistical analysis, drafting the article, revising the article critically for important intellectual content, final approval of the version to be published. GBF MARQUES, conception and design, acquisition of data, statistical analysis, drafting the article, revising the article critically for important intellectual content, final approval of the version to be published. ACFR PROENÇA, conception and design, acquisition of data, statistical analysis, drafting the article, revising the article critically for important intellectual content, final approval of the version to be published. EN PEDREIRA, conception and design, revising the article critically for important intellectual content, final approval of the version to be published.

\section{SHCN.pdf>.}

5. Farias N, Buchalla CM. A classificação internacional de funcionalidade, incapacidade e saúde da Organização Mundial da Saúde: conceitos, usos e perspectivas. Rev Bras Epidemiol. 2005;8(2):187-93. doi: 10.1590/S1415-790X2005000200011

6. Santos MTBR, Haddad AS. Quem são os pacientes com necessidades especiais? In: Cardoso RJA, Machado MEL. Odontologia: arte e conhecimento. São Paulo: Artes Médicas; 2003. p.263-8.

7. Sonis ST, Fazio RC, Fang L. História, avaliação física e laboratorial. In: Sonis ST, Fazio RC, Fang L. Princípios e prática de medicina oral. $2^{a}$ ed. Rio de Janeiro: Guanabara Koogan; 1996. p. 3-18.

8. Pinto BM, Machado CJ, Sá EO. Características necessárias de um profissional de saúde que trabalha com pacientes portadores de necessidades especiais: um contraste de visões de profissionais e alunos de odontologia, pais e educadores. Belo Horizonte: UFMG/Cedeplar; 2004. 
9. Miley DD, Terezhalmy GT. The patient with diabetes mellitus: Etiology, epidemiology, principles of medical management, oral disease burden, and principles of dental management. Quintessence Int. 2005;36(10):779-95.

10. Selwitz RH, Pihlstrom BL. How to lower risk of developing diabetes and its complications: Recommendations for the patient. J Am Dent Assoc. 2003;134:54-8. doi: 10.14219/jada. archive.2003.0373

11. Haddad AS, Castilho AL. Doenças sistêmicas crônicas. In: Haddad AS. Odontologia para pacientes com necessidades especiais. São Paulo: Santos; 2007. p. 263-76.

12. Bandeira F, Graf H, Griz L, Faria M, Lazaretti-Castro M, Mancini M. Endocrinologia e diabetes. Rio de Janeiro: Medsi, 2003.

13. Castro MVM, Pereira Al, Duarte CA, Cavalcante AG, Queiroz IKR. Atendimento clínico conjunto entre o periodontista e o médico. Parte I: diabetes e doenças isquêmicas. ROBRAC. 2000;9(28):55-58.

14. Kaur G, Holtfreter B, Rathmann W, Schwahn C, Wallaschofski H, Schipf $S$, et al. Association between type 1 and type 2 diabetes with periodontal disease and tooth loss. J Clin Periodontol. 2009 Sep;36(9):765-74. doi: 10.1111/j.1600-051X.2009.01445.x

15. Zárate OG. Actualidades en el manejo dental del paciente diabético. Rev Asoc Dental Mexic. 1999;44(1):18-26.

16. Wannmacher L, Ferreira MB. Farmacologia clínica para dentistas Rio de Janeiro: Guanabara; 1999.

17. Vernillo AT. Dental considerations for the treatment of patients with diabetes mellitus. The J Am Dent Assoc. 2003;134:24-33.

18. Tily FE, Thomas S. Glycemic effect of administration of epinephrine-containing local anaesthesia in patients undergoing dental extraction, a comparison between healthy and diabetic patients. Int Dent J. 2007 Apr;57(2):77-83.

19. Saraceni JR, Armonia PL. Terapêutica medicamentosa em Odontologia. São Paulo: Médica; 1981.

20. Mazzoni A. Conduta odontológica para atendimento de pacientes hemofílicos [citado 2017 Apr 2]. Disponível em: $<$ http://www.apcd.org.br>.

21. 21 - Brasil. Ministério da Saúde. Secretaria de Atenção à Saúde. Departamento de Atenção Especializada. Manual de atendimento odontológico a pacientes com coagulopatias hereditárias. Brasília: Ministério da Saúde; 2005.

22. Sonis ST, Fazio RC, Fang L. Medicina oral. Rio de Janeiro: Guanabara Koogan; 1987
23. Prado MCP, Silveira FRX, Birman EG. Hemofilia: aspectos de interesse odontológico. Rev Pós-Grad. 1994;1(2):32-5.

24. Souza MOF, Perez ARHS, Souza TOF, Martins MAT, Bussadori SK, Fernandes KPS, et al. Incidência de alterações sistêmicas e uso de medicamentos em pacientes atendidos em clínica odontológica. Conscientiae Saúde. 2007:6(2):305-11.

25. Sonis ST, Fazio RC, Fang LF. Princípios e prática de medicina oral. $2^{\circ}$ ed. Rio de Janeiro: Guanabara Koogan; 1996.

26. de Barros MNF, Gaujac C, Trento $C L$, de Andrade $M C V$. Tratamento de pacientes cardiopatas na clínica odontológica. Rev Saúde Pesq. 2011;4(1):109-114.

27. Araújo LC, Bavaresco CS. Verificação do conhecimento e da conduta de odontólogos em relação ao manejo do paciente cardiopata na atenção primária à saúde. Rev APS. 2011;14(2):197-206.

28. Braunwald E, Isselbacher KJ, Petersdorf RG, Wilson JD, Martin JB, Fauci AS. Harrison: principios de medicina Interna. $17^{\mathrm{a}}$ ed. México: Mc Graw Hill; 2008.

29. Montero SR, Basili AE, Castellón LZ. Manejo odontológico del paciente con insuficiencia renal crónica. Rev Dent Chile. 2002:93(2):14-8.

30. Ziccardi VB, Saini J, Demas PN, Braun TW. Management of the oral and maxillofacial surgery patient with endstage renal disease. J Oral Maxillofac Surg. 1992;50(11):1207-12. doi: 10.1016/0278-2391(92)90155-S

31. Sonis ST, Fazio RC, Fang L. Insuficiência renal crônica, diálise e transplante. In: Sonis ST, Fazio RC, Fang L. Princípios e prática de medicina oral. $2^{\text {a }}$ ed. Rio de Janeiro: Guanabara Koogan; 1996. p. 251-60.

32. Fujimaki M, Rosa OPS, Torres SA. Microorganismos cariogênicos em pacientes com insuficiência renal crônica em hemodiálise. Rev Odontol Univ São Paulo. 1998;12(2):149-58.

Proctor R, Kumar N, Stein A, Moles D, Porter S. Oral and dental aspects of chronic renal failure. J Dent Res. 2005;84(3):199-208.

Received on: 4/4/2017

Final version resubmitted on: 20/6/2017 Approved on: 21/8/20187 